\title{
Recurrent arthritis caused by Candida parapsilosis: a case report and literature review
}

\author{
Hang Fang ${ }^{1,2,3 \dagger}$ D, Lisi Huang ${ }^{4 \dagger}$, Rongkai Zhang ${ }^{1,2,3}$, Denghui Xie ${ }^{1,2,3}$, Hengbiao Sun ${ }^{5}$, Chun Zeng ${ }^{1,2,3}$ and \\ Daozhang Cai ${ }^{1,2,3^{*}}$
}

\begin{abstract}
Background: Candida arthritis is extremely rare and also represents a major challenge of diagnosis and treatment. Here we reported a rare case of recurrent arthritis caused by Candida parapsilosis.

Case presentation: A 56-year-old Chinese male suffered from recurrent pain and swelling in his right knee after several times of "small needle-knife" acupuncture and corticosteroid injection of the joint. Candida parapsilosis was cultured in his synovial fluid and identified by sequencing of its Internal Transcribed Spacer (ITS) gene. Here we present the radiological characteristics, arthroscopic pictures, and synovium pathology of this patient. Also, blood test and chemical analysis of his synovial fluid were listed as well as the ITS sequence of this Candida species identified. The patient underwent thorough arthroscopic debridement and then set on fluconazole $400 \mathrm{mg}$ daily for 12 months. His symptoms resolved and no relapse was observed on the last follow-up. Additionally, a brief but comprehensive review of C. parapsilosis arthritis episodes from past to now were studied.

Conclusion: With the detailed clinical information reported in this case and our literature review, we hope they would add to our knowledge of C. parapsilosis arthritis - its clinical settings, laboratory features, radiological characteristics, arthroscopic findings and experience of management.
\end{abstract}

Keywords: Knee joint, Recurrent arthritis, Candida parapsilosis, Fluconazole

\section{Background}

Candida arthritis is extremely rare and also represents a major challenge of diagnosis and treatment because the clinical manifestations, laboratory and radiologic findings are not specific and not well defined [1,2]. Among Candida species, Candida albicans contributes the highest incidence of cases with Candida arthritis [3]. Whereas, the reports of $C$. parapsilosis arthritis was infrequent and limited to individual case descriptions. In this study, we reported a rare case of fungal arthritis due to C. parapsilosis seen at the Orthopedics Department

\footnotetext{
* Correspondence: caidaozhang@gmail.com

${ }^{+}$Hang Fang and Lisi Huang contributed equally to this work.

'Department of Orthopaedics, The Third Affiliated Hospital of Southern

Medical University, Zhongshan Ave. West, Guangzhou 510630, People's

Republic of China

${ }^{2}$ Academy of Orthopaedics, Guangdong Province, 183 Zhongshan Ave. West,

Guangzhou 510630, People's Republic of China

Full list of author information is available at the end of the article
}

of the Third Affiliated Hospital of Southern Medical University. Furthermore, we conducted a systematic review of C. parapsilosis arthritis episodes from past to now.

\section{Case presentation}

A 56-year-old man was admitted to our hospital because of recurrent pain and impaired range of motion (ROM) of his right knee for over a year. His medical history included type 2 diabetes and hypertension which were poorly controlled. He told us his knee was mild painful and swollen at the first place about one year ago without any injury. He went to a local hospital of Traditional Chinese Medicine (TCM) and was treated with "small needle-knife acupuncture" and ozone injection into the knee joint for several times. His symptoms became better after these treatments. However, 2-3 months later, his knee pain and swelling came back and he was again

(c) The Author(s). 2019 Open Access This article is distributed under the terms of the Creative Commons Attribution 4.0 International License (http://creativecommons.org/licenses/by/4.0/), which permits unrestricted use, distribution, and 
treated with acupuncture and TCM plaster, as well as joint aspirations with corticosteroid injection. After these therapies his knee was painless for another 2 months before it became swollen and painful again. Approximately 5-6 times of aspirations and corticosteroid injections were given to him, but the time-period of pain-release became shorter and shorter.

On admission, he was afebrile, $\mathrm{T} 36.2^{\circ} \mathrm{C}$, BP $133 / 70$ $\mathrm{mmHg}, \mathrm{P} 83 / \mathrm{min}, \mathrm{R} 16 / \mathrm{min}$. His right knee joint was obviously swelling. A $3 \mathrm{~cm} \times 3 \mathrm{~cm}$ local bump on anterolateral knee can be inspected, which was soft and painless on palpation. Joint line tenderness was present, and floating patella test was positive. His right knee has impaired ROM $\left(100^{\circ}-0-0^{\circ}\right)$ and was painful when overextension or over-flexion. Anterior drawer test, Lachman test and McMurray test were negative.

Blood tests showed elevated erythrocyte sedimentation rate (ESR, $29 \mathrm{~mm} / \mathrm{h}$, reference range $<20 \mathrm{~mm} / \mathrm{h}$ ) and C-reactive protein (CRP, $18.38 \mathrm{mg} / \mathrm{L}$, reference range $<8 \mathrm{mg} / \mathrm{L}$ ), while the white blood cell (WBC, $7.3 \times 10^{9} / \mathrm{L}$, reference range $3.4-10.0 \times 10^{9} / \mathrm{L}$ ) count and hemoglobin $(\mathrm{HB}, 140 \mathrm{~g} / \mathrm{L}$, reference range 131$172 \mathrm{~g} / \mathrm{L}$ ) were normal. Radiographs of both knees exhibited the formation of osteophytes and narrowing of joint space on the medial compartments which indicated osteoarthritis (Fig. 1a). MRI T2-weighted and SPAIR sequences demonstrated subchondral bone marrow edema in the lateral femoral condyle, and the presence of soft-tissue abnormalities, including capsulitis, extensive synovial hyperplasia, capsular fluid collection, and periarticular muscle edema (Fig. 1b).

The patient then underwent thorough arthroscopic debridement and partial meniscectomy of his right knee. Inflammatory synovium was observed under the arthroscopy (Fig. 1c). Meanwhile, his thick, yellow and turbid synovial fluid was harvested. The biochemical and cytological analyses of joint fluid were as follows: Rivalta test, +++ ; total cell, $454 \times 10^{9} / \mathrm{L} ; \mathrm{WBC}, 155 \times 10^{9} / \mathrm{L}(22 \%$ mononuclear neutrophils and $78 \%$ polymorphonuclear neutrophils); protein, $37.7 \mathrm{~g} / \mathrm{L}$; lactate dehydrogenase (LDH), $1841 \mathrm{U} / \mathrm{L}$. The Gram stain and acid-fast stain of the fluid demonstrated no bacteria or tuberculosis. Representative isolates of Candida were cultured in the Sabouraud dextrose agar medium (Fig. 1d). Subsequently, Candida species was identified by Internal Transcribed Spacer (ITS) sequencing [4] (forward primer ITS1, 5'-TCCGTAGGTGAACTTGCGG3'; reverse primer ITS4, 5'-TCCTCCGCTTATTGATATGC-3') and confirmed as C. parapsilosis by BLAST on NCBI (http://www.ncbi.nlm.nih.gov/). The sequence of ITS gene amplified from this isolate was listed in Additional file 1. Notably, the budding cells and pseudohyphae were also observed in the synovial tissue by periodic acid-schiff (PAS) staining (Fig. 1e), which further confirmed the diagnosis of Candida arthritis. Susceptibility test was performed and

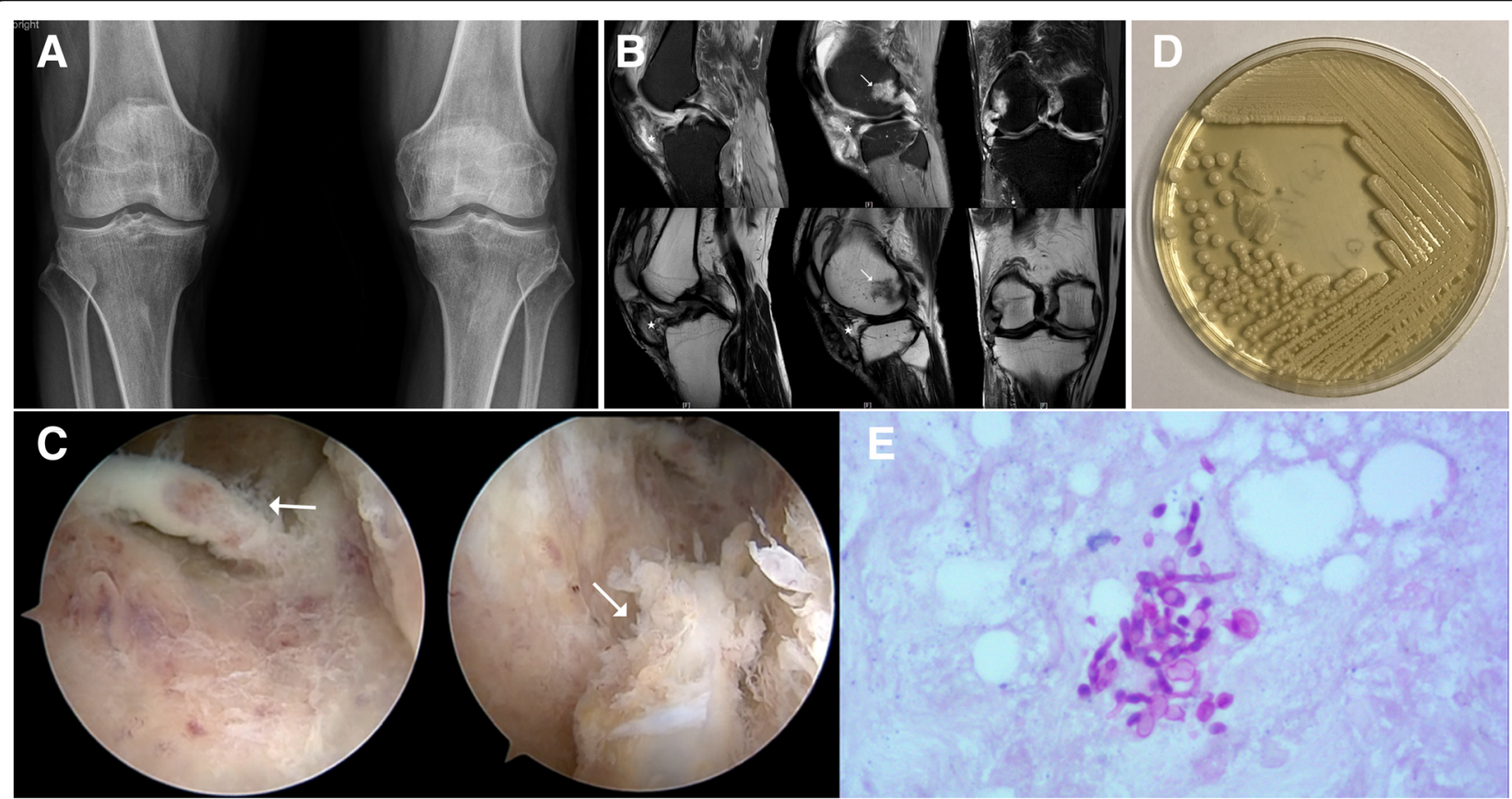

Fig. 1 A 56-year-old man with fungal arthritis of the right knee due to Candida parapsilosis. a X-ray showed degenerative arthritis of bilateral knee. b MRI T2-weighted and SPAIR sequences demonstrated subchondral bone marrow edema in the lateral femoral condyle, and the presence of soft-tissue abnormalities, including capsulitis, extensive synovial hyperplasia, capsular fluid collection, and periarticular muscle edema. c Under the arthroscope, inflammatory synovium was observed. $\mathbf{d}$ Representative isolates of Candida were cultured from the synovial fluid in the Sabouraud medium. e PAS staining revealed the budding cells and pseudohyphae of Candida parapsilosis in the synovial tissue 
yielded susceptibilities to 5-flurocytosine, amphotericin B, fluconazole, itraconazole, and voriconazole.

The patient was then treated with fluconazole $400 \mathrm{mg}$ daily intravenously for three weeks and then switched to orally for one year. The pain and swelling of the knee subsided gradually, and the patient had no complaints of the aforementioned symptoms 4 weeks post-surgery. On one-year follow-up, the patient remained in a clinically stable condition and the last culture of joint fluid was negative for C. parapsilosis.

\section{Discussion}

In the present study, the patient manifested with a mild chronic knee arthritis characterized by recurrent pain and swelling, leading to a diagnostic delay that lasted for almost one year. Fortunately, mycologic investigation was performed in his first visit to our hospital and $C$. parapsilosis was identified in the joint fluid and synovial tissue. Previously, many lines of evidence have indicated that most patients with fungal infection are immunosuppressed with predisposing factors, including systemic disease, recent surgery, chemotherapy, longterm antibiotics use, corticosteroid therapy and insertion of central venous catheters $[5,6]$. In the current case, the patient had poorly controlled blood glucose and several events of corticosteroid injection of his knee which might cause global and local impairment of immunity. Besides, TCM treatment such as "small needle-knife acupuncture" might also predispose the knee to local inoculation of pathogen if equipment was not well sterilized. Owing to these risk factors, the possibility of fungal infection should be taken into consideration.

C. parapsilosis is an opportunistic human pathogenic fungal species and also an uncommon cause of septic arthritis. From 1979 to 2019 there were not more than 20 cases of $C$. parapsilosis arthritis reported in the English literature. In this study, we collected 16 available cases (including one case from the current report) which the final diagnoses were made by the mycological culture and exhibited in Table 1 [7-19]. The data suggested that local pain and swelling were the most common clinical manifestations of $C$. parapsilosis arthritis, while fever and erythema occurred infrequently. Since the symptoms are always mild and unspecific, the diagnosis can often be delayed. For the patients with recurrent infection and underlying immunosuppression, clinicians should raise the suspicion of fungal infection. Moreover, our review showed that $C$. parapsilosis arthritis could occur in the knee (10/16), hip (2/16), shoulder (4/16) and wrist $(1 / 16)$. Knee was the most frequently infected site, which was similar to the previous studies on Candida arthritis [3, 20], and almost all cases were monoarticular infection except one.
In addition, the cases demonstrated a wide range of underlying conditions, including surgery, diabetes mellitus, rheumatoid arthritis, renal transplantation, hemodialysis, intravenous drug addiction and HIV infection. Notably, the majority of episodes (10/16) were associated with secondary infection due to arthroplasty. Previous studies have revealed that the risk of infectious complications after joint replacement is estimated at 1$3 \%$ and fungal agents contribute $1 \%$ of prosthetic infections, among of which $C$. albicans is the most frequent species followed by $C$. parapsilosis $[17,21,22]$. It is now widely accepted that the majority of Candida infections are related to biofilm formation on the host tissue or on the surfaces of medical devices or prostheses. C. parapsilosis biofilms are thinner, less structured and comprised exclusively of clumped blastospores in comparison with C. albicans, which may be attributed to their lower pathogenicity [23]. Our review indicated that surgical treatment was an essential approach to eradicate the prosthetic infection. Out of ten patients, seven underwent resection arthroplasty, among of which one also had reimplantation. While the other two received surgical debridement, total synovectomy and two-stage reimplantation, respectively, and only one was treated successfully with antifungal agents alone. The latter patient without predisposing factors developed right knee arthritis due to $C$. parapsilosis 8 weeks after arthroscopic arthroplasty and was given amphotericin B $(0.7 \mathrm{mg} / \mathrm{kg} /$ day $)$ intravenously for 3 weeks followed by oral suppressive treatment with fluconazole $(400 \mathrm{mg}$ / day) for 6 months, which brought a favorable outcome without surgery [18]. However, the success rate of antifungal treatment alone is very low. Presently, the treatment of Candida prosthetic infection is still not clearly defined. In North America, the association of long-term antifungal use with two-stage exchange arthroplasty is considered as the gold standard management for prosthetic infection [24]. However, Fernando Cobo et al. pointed out that one-stage exchange arthroplasty or antifungal treatment alone was also possible to obtain a favorable outcome [25]. Additionally, all patients received antifungal therapy, with a single drug in ten cases, with two drugs in five cases and more than two in one. Among these six cases with two or more antifungal agents, only one was mentioned to have performed susceptibility test for $C$. parapsilosis isolate. As the emergence of antifungal resistance increases gradually, antifungal susceptibility testing is recognized as a useful aid in selecting the most appropriate antifungal agent, especially for treating serious forms of candidiasis [26, 27]. In our literature review, most of cases commonly began with amphotericin B or fluconazole with or without combinations, such as flucytosine. Moreover, ketoconazole was given in some cases, but we 
Table 1 Clinical features of the patients with Candida parapsilosis arthritis in the literatures

\begin{tabular}{|c|c|c|c|c|c|c|}
\hline $\begin{array}{l}\text { Patient No. } \\
\text { (reference/year of } \\
\text { publication) }\end{array}$ & $\begin{array}{l}\text { Age } \\
\text { (years) } \\
\text { /sex }\end{array}$ & $\begin{array}{l}\text { Localization } \\
\text { of infection }\end{array}$ & Underlying conditions & Clinical manifestations & Therapy & Outcome \\
\hline $1(7) / 1979$ & $64 / M$ & Knee & $\begin{array}{l}\text { Immunosuppression, } \\
\text { intraarticular joint } \\
\text { injections, total knee } \\
\text { arthroplasty }\end{array}$ & Pain and swelling & $\begin{array}{l}\text { Resection Arthroplasty, AMB } \\
+5 \text {-FC for } 3 \text { months }\end{array}$ & $\begin{array}{l}\text { Cured. No } \\
\text { recurrence after } 1 \\
\text { year of follow-up }\end{array}$ \\
\hline $2(8) / 1983$ & $59 / \mathrm{M}$ & Shoulder & $\begin{array}{l}\text { Drug abuse, } \\
\text { hemiarthroplasty }\end{array}$ & Pain and swelling & $\begin{array}{l}\text { Resection Arthroplasty, AMB } \\
\text { followed by KZ }\end{array}$ & Cured. \\
\hline $3(9) / 1984$ & $57 / M$ & knee & End stage renal disease & Swelling & $\begin{array}{l}\text { High dose of AMB for over } 2 \\
\text { months }\end{array}$ & $\begin{array}{l}\text { Remission } \\
\text { (defer further } \\
\text { treatment) }\end{array}$ \\
\hline $4(10) / 1986$ & $70 / F$ & Shoulder & hemiarthroplasty & Pain and swelling & Resection Arthroplasty, AMB & Cured. \\
\hline $5(10) / 1986$ & $35 / M$ & Knee & Total knee arthroplasty & Swelling & $\begin{array}{l}\text { Resection Arthroplasty, 5-FC } \\
\text { (duration NR) }\end{array}$ & NR. \\
\hline $6(11) / 1993$ & $37 / M$ & Knee & $\begin{array}{l}\text { HIV infection, } \\
\text { Hemophilia, total knee } \\
\text { replacement, septic } \\
\text { arthritis }\end{array}$ & Erythema and pain & $\begin{array}{l}\text { Resection arthroplasty; FZ for } \\
6 \text { months }\end{array}$ & Cured. \\
\hline $7(12) / 1998$ & $64 / \mathrm{M}$ & knee & $\begin{array}{l}\text { Diabetes, total knee } \\
\text { arthroplasty }\end{array}$ & swelling & $\begin{array}{l}\text { Irrigation, debridement and } \\
\text { drainage; total synovectomy; } \\
\text { AMB for } 4 \text { months followed by } \\
\text { FZ for } 3 \text { months }\end{array}$ & $\begin{array}{l}\text { Cured. No } \\
\text { recurrence after } 2 \\
\text { years of follow-up }\end{array}$ \\
\hline $8(13) / 2001$ & $68 / F$ & Knee & total knee arthroplasty & Pain & $\begin{array}{l}\text { Resection arthroplasty, } \\
\text { FZ for } 10 \text { weeks, Reimplantation } \\
\text { at } 3 \text { months }\end{array}$ & Cured. \\
\hline $9(14) / 2002$ & $38 / F$ & Knee & $\begin{array}{l}\text { Diabetes, renal } \\
\text { transplantation }\end{array}$ & $\begin{array}{l}\text { Fever, swelling and } \\
\text { tenderness }\end{array}$ & $\begin{array}{l}\text { Arthroscopic irrigation, FZ + 5-FC } \\
\text { for over } 1 \text { year }\end{array}$ & $\begin{array}{l}\text { Cured. No } \\
\text { recurrence after over } \\
1 \text { year of follow-up }\end{array}$ \\
\hline $10(15) / 2006$ & $50 / \mathrm{M}$ & shoulder & $\begin{array}{l}\text { Drug abuse, HIV } \\
\text { infection }\end{array}$ & Pain with fistula & $\begin{array}{l}\text { Debridement; caspofungin for } 6 \\
\text { weeks }\end{array}$ & Cured. \\
\hline $11(16) / 2008$ & $65 / F$ & $\begin{array}{l}\text { Knee and } \\
\text { shoulder }\end{array}$ & $\begin{array}{l}\text { Diabetes, secondary } \\
\text { renal failure, renal } \\
\text { transplantation }\end{array}$ & $\begin{array}{l}\text { Pain, swelling and } \\
\text { redness }\end{array}$ & FZ for 2 months & $\begin{array}{l}\text { Cured. No } \\
\text { recurrence after } 6 \\
\text { months of follow-up }\end{array}$ \\
\hline $12(17) / 2010$ & $66 / M$ & Hip & $\begin{array}{l}\text { Chronic kidney failure, } \\
\text { previous Serratia } \\
\text { marcescens prosthesis } \\
\text { infection }\end{array}$ & Post-operative fistula & $\begin{array}{l}\text { 2-stage reimplantation; FZ } \\
\text { for } 6 \text { months }\end{array}$ & Cured. \\
\hline $13(17) / 2010$ & $77 / F$ & Hip & $\begin{array}{l}\text { Previous coagulase- } \\
\text { negative Staphylococcus } \\
\text { prosthesis infection }\end{array}$ & $\begin{array}{l}\text { Fever and erythema } 5 \\
\text { months after treatment } \\
\text { for bacterial prosthesis } \\
\text { infection }\end{array}$ & $\begin{array}{l}\text { Resection arthroplasty; AMB } \\
+5 \text {-FC for } 2 \text { weeks followed } \\
\text { by FZ for } 9 \text { months }\end{array}$ & Cured. \\
\hline $14(18) / 2010$ & $48 / F$ & Knee & arthroscopic arthroplasty & Pain and swelling & $\begin{array}{l}\text { AMB for } 3 \text { weeks followed by } \\
\text { FZ for } 6 \text { months }\end{array}$ & Cured. \\
\hline $15(19) / 2012$ & $60 / F$ & Wrist & rheumatoid arthritis & Swelling & $\begin{array}{l}\text { Surgical debridement and wrist } \\
\text { arthrodesis; FZ for life }\end{array}$ & Cured. \\
\hline $16(C R)$ & $56 / \mathrm{M}$ & Knee & $\begin{array}{l}\text { Diabetes, intraarticular } \\
\text { joint injections }\end{array}$ & Pain and swelling & $\begin{array}{l}\text { Surgical debridement; FZ for } 1 \\
\text { year }\end{array}$ & $\begin{array}{l}\text { Cured. No } \\
\text { recurrence after } 1 \\
\text { year of follow-up }\end{array}$ \\
\hline
\end{tabular}

$\overline{A M B}$, amphotericin $\mathrm{B} ; \mathrm{FZ}$, fluconazole; 5-FC, flucytosine; $\mathrm{KZ}$, ketoconazole; $\mathrm{NR}$, not reported; CR, current report

have to mention that its systemic administration is no longer recommended due to growing evidences of hepatotoxicity, endocrine dysregulation, several drug interactions, and death [28]. Furthermore, echinocandins, including caspofungin, anidulafungin, and micafungin, are promising in Candida arthritis, especially for the patients with fluconazole resistant and/or intolerant to voriconazole [15]. Recently, fluconazole is supposed to be superior to echinocandins for the treatment of $C$. parapsilosis arthritis on the basis of the decreased in vitro activity of echinocandins against $C$. parapsilosis and reports of echinocandin resistance among selected 
isolates [29-31]. Of special note, treatment of Candida arthritis remains a big challenge with the risk of relapse, thus a constantly long-term monitoring is still recommended.

In conclusion, our study reported the literature review of C. parapsilosis arthritis for the first time, which might help to add our knowledge of its clinical settings and experience of management. On the other hand, we have to admit the limitation that our review can not fully reflect the clinical characteristics of the disease since there are still a quite small number of relevant cases covered. Following the incremental use of immunosuppressive therapies together with broad-spectrum antibiotic treatment as well as the increasing number of patients implanted with joint arthroplasties, the incidence of $C$. parapsilosis arthritis has increased gradually. The timely diagnosis is of great importance to help initiate antifungal therapy promptly, prevent cartilage destruction as well as preserve joint functions.

\section{Additional file}

Additional file 1: The sequence of ITS gene amplified from the representative isolate of Candida. (TXT 493 bytes)

\section{Abbreviations}

CRP: C-reactive protein; ESR: Erythrocyte sedimentation rate; HB: Hemoglobin; ITS: Internal Transcribed Spacer; LDH: Lactate dehydrogenase; PAS: Periodic acid-schiff; ROM: Range of motion; TCM: Traditional Chinese Medicine; WBC: White blood cell

\section{Acknowledgements}

Not applicable.

\section{Authors' contributions}

DZC, CZ and HF did the study design. HF, LSH and RKZ did the data collection and wrote the manuscript draft. DZC and CZ did the data interpretation. DHX and HBS did the laboratory tests and pathogen identification. CZ and DZC performed the arthroscopic surgery. All authors have read and approved the manuscript.

\section{Funding}

No funding was received.

\section{Availability of data and materials}

The data that support the findings of this study are available from the corresponding author (DZC) upon reasonable request.

\section{Ethics approval and consent to participate}

Not applicable.

\section{Consent for publication}

Written informed consent for the publication of the case report was obtained from the patient. A copy of the written consent is available for review by the editor of this journal.

\section{Competing interests}

All authors declare no competing interests.

\section{Author details}

'Department of Orthopaedics, The Third Affiliated Hospital of Southern Medical University, Zhongshan Ave. West, Guangzhou 510630, People's Republic of China. '2Academy of Orthopaedics, Guangdong Province, 183
Zhongshan Ave. West, Guangzhou 510630, People's Republic of China. ${ }^{3}$ Orthopaedic Hospital of Guangdong Province, 183 Zhongshan Ave. West, Guangzhou 510630, People's Republic of China. ${ }^{4}$ Department of Clinical Laboratory, Sun Yat-Sen Memorial Hospital, Sun Yat-Sen University, 107 Yanjiang West Road, Guangzhou 510120, People's Republic of China. ${ }^{5}$ Department of Clinical Laboratory, The Third Affiliated Hospital of Southern Medical University, 183 Zhongshan Ave. West, Guangzhou 510630, People's Republic of China.

Received: 12 April 2019 Accepted: 3 July 2019

Published online: 17 July 2019

\section{References}

1. Azzam K, Parvizi J, Jungkind D, Hanssen A, Fehring T, Springer B, et al. Microbiological, clinical, and surgical features of fungal prosthetic joint infections: a multi-institutional experience. J Bone Joint Surg Am. 2009; 91(Suppl 6):142-9.

2. Taneja AK, Torriani M, Simeone FJ. Septic arthritis and osteomyelitis of the hip by Candida albicans. J Rheumatol; 2014;41:2270-0.

3. Gamaletsou MN, Rammaert B, Bueno MA, Sipsas NV, Moriyama B, Kontoyiannis DP, et al. Candida arthritis: analysis of 112 pediatric and adult cases. Open Forum Infect Dis. 2016;3:ofv207.

4. Schoch $C L$, Seifert KA, Huhndorf S, Robert V, Spouge $J$, Levesque CA, et al. Nuclear ribosomal internal transcribed spacer (ITS) region as a universal DNA barcode marker for fungi. Proc Natl Acad Sci U S A. 2012;109:6241-6.

5. Bariteau JT, Waryasz GR, McDonnell M, Fischer SA, Hayda RA, Born CT. Fungal osteomyelitis and septic arthritis. J Am Acad Orthop Surg. 2014;22:390-401.

6. Henry MW, Miller AO, Walsh TJ, Brause BD. Fungal Musculoskeletal Infections. Infect Dis Clin N Am. 2017;31:353-68.

7. MacGregor RR, Schimmer BM, Steinberg ME. Results of combined amphotericin B-5-fluorcytosine therapy for prosthetic knee joint infected with Candida parapsilosis. J Rheumatol. 1979;6:451-5.

8. Lichtman EA. Candida infection of a prosthetic shoulder joint. Skelet Radiol. 1983;10:176-7.

9. Mandel DR, Segal AM, Wysenbeek AJ, Calabrese LH. Two unusual strains of Candida arthritis. Am J Med Sci. 1984;288:25-7.

10. Lim EV, Stern PJ. Candida infection after implant arthroplasty. A case report. J Bone Joint Surg Am. 1986:68:143-5.

11. Tunkel AR, Thomas CY, Wispelwey B. Candida prosthetic arthritis: report of a case treated with fluconazole and review of the literature. Am J Med. 1993;94:100-3.

12. Brooks DH, Pupparo F. Successful salvage of a primary total knee arthroplasty infected with Candida parapsilosis. J Arthroplast. 1998;13:707-12.

13. Yang SH, Pao JL, Hang YS. Staged reimplantation of total knee arthroplasty after Candida infection. J Arthroplast. 2001;16:529-32.

14. Vasquez JC, Hart M, Denney CF, Pedowitz R, Ziegler EJ. Fungal arthritis of the knee caused by Candida parapsilosis in a kidney transplant recipient. J Clin Rheumatol. 2002;8:147-50.

15. Legout L, Assal M, Rohner P, Lew D, Bernard L, Hoffmeyer P. Successful treatment of Candida parapsilosis (fluconazole-resistant) osteomyelitis with caspofungin in a HIV patient. Scand J Infect Dis. 2006;38:728-30.

16. Masoud M, Nasser NJ, Karban A, Edelstein S. Candida parapsilosis septic arthritis in a renal transplant patient. J Clin Rheumatol. 2008;14:56.

17. Dutronc H, Dauchy FA, Cazanave C, Rougie C, Lafarie-Castet S, Couprie B, et al. Candida prosthetic infections: case series and literature review. Scand J Infect Dis. 2010;42:890-5.

18. Lee C-H, Oh J-M, Oh S-R, Yoo M, Lee M-S. Candida arthritis after arthroscopic arthroplasty in a patient without predisposing factors. Open Rheumatol J. 2010;4:7-9.

19. Miyamoto H, Miura T, Morita E, Morizaki $Y$, Uehara K, Ohe T, et al. Fungal arthritis of the wrist caused by Candida parapsilosis during infliximab therapy for rheumatoid arthritis. Mod Rheumatol Taylor \& Francis. 2012;22:903-6.

20. Cobo F, Rodríguez-Granger J, López EM, Jiménez G, Sampedro A, Aliaga-Martínez L, et al. Candida-induced prosthetic joint infection. A literature review including 72 cases and a case report. Infect Dis (Lond). 2017;49:81-94.

21. Kojic EM, Darouiche RO. Candida infections of medical devices. Clin Microbiol Rev American Society for Microbiology (ASM). 2004;17:255-67. 
22. Allon R, Ben Basat N, Puhov A, Zaulan Y, Wollstein R. Critical evaluation of the ability to diagnose periprosthetic infection in a medical system in Israel. Harefuah. 2018;157:210-3.

23. Kuhn DM, Chandra J, Mukherjee PK, Ghannoum MA. Comparison of biofilms formed by Candida albicans and Candida parapsilosis on bioprosthetic surfaces. Infect Immun American Society for Microbiology (ASM). 2002;70:878-88.

24. Parvizi J, Adeli B, Zmistowski B, Restrepo C, Greenwald AS. Management of periprosthetic joint infection: the current knowledge: AAOS exhibit selection. J Bone Joint Surg Am. 2012;94:e104--9.

25. Cobo F, Rodríguez-Granger J, Sampedro A, Aliaga-Martínez L, Navarro-Mari JM. Candida prosthetic joint infection. A review of treatment methods. J Bone Jt Infect. 2017;2:114-21.

26. Pfaller MA, Diekema DJ, Sheehan DJ. Interpretive breakpoints for fluconazole and Candida revisited: a blueprint for the future of antifungal susceptibility testing. Clin Microbiol Rev. 2006;19:435-47.

27. Ostrosky-Zeichner L, Andes D. The role of in vitro susceptibility testing in the Management of Candida and Aspergillus. J Infect Dis. 2017;216:5452-7.

28. Gupta AK, Lyons DCA. The rise and fall of Oral ketoconazole. J Cutan Med Surg. 2015;19:352-7.

29. Walsh TJ. Echinocandins--an advance in the primary treatment of invasive candidiasis. N Engl J Med. 2002;347:2070-2.

30. Bennett JE. Echinocandins for candidemia in adults without neutropenia. $N$ Engl J Med. 2006;355:1154-9.

31. Wiederhold NP, Lewis RE. The echinocandin antifungals: an overview of the pharmacology, spectrum and clinical efficacy. Expert Opin Investig Drugs Taylor \& Francis. 2003;12:1313-33.

\section{Publisher's Note}

Springer Nature remains neutral with regard to jurisdictional claims in published maps and institutional affiliations.

Ready to submit your research? Choose BMC and benefit from:

- fast, convenient online submission

- thorough peer review by experienced researchers in your field

- rapid publication on acceptance

- support for research data, including large and complex data types

- gold Open Access which fosters wider collaboration and increased citations

- maximum visibility for your research: over $100 \mathrm{M}$ website views per year

At BMC, research is always in progress.

Learn more biomedcentral.com/submissions 